\title{
Proses Berpikir Matematis Siswa dalam Menyelesaikan Masalah Matematika Ditinjau dari Tipe Kepribadian Keirsey
}

\author{
Khusnul Khamidah ${ }^{1}$, Suherman ${ }^{2}$ \\ 1,2 IAIN Raden Intan Lampung: suherman_alghifari@yahoo.co.id
}

\begin{abstract}
This study aims to describe the mathematical thinking process of students in solving mathematical problems in terms of Keirsey personality types. This research is a descriptivequalitative research. The research subjects were students of MAN 2 Tulang Bawang Barat class XI by purposive sampling. Research subjects were 2 people from each personality type. Data collection is done by means of observation, interviews, and documentation. Data validity uses technical triangulation. Data analysis techniques used are the Miles and Huberman concepts, namely data reduction, data presentation, and conclusion drawing. The results showed that each student with Keirsey personality type in solving mathematical problems was more likely to be a Guardian type student. in solving mathematical problems starting with the receipt of information marked by understanding the problem including knowing what is known (M1), knowing what is asked (M2), knowing the requirements in problem solving (M3), and making a mathematical model of the problem with own understanding (M4). Then proceed with processing information marked by implementing a problem solving plan (R1) and proceed with implementing the plan to get an answer (P1), but the steps are incomplete. Whereas in checking the answers (C1) the student checks again, then in drawing conclusions (C2), students draw conclusions only on some tests.
\end{abstract}

Keywords: Mathematical thinking process; Keirsey personality.

\begin{abstract}
Abstrak
Penelitian ini bertujuan untuk mendeskripsikan proses berpikir matematis siswa dalam meyelesaikan masalah matematika ditinjau dari tipe kepribadian Keirsey. Penelitian ini merupakan penelitian kualitatif-deskriptif. Subjek penelitian yang diambil adalah siswa MAN 2 Tulang Bawang Barat kelas XI dengan cara purposive sampling. Subjek penelitian berjumlah 2 orang dari masing-masig tipe kepribadian. Pengumpulan data dilakukan dengan cara observasi, wawancara, dan dokumentasi. Validitas data menggunakan triangulasi teknik. Teknik analisis data yang digunakan adalah konsep Miles dan Huberman, yaitu reduksi data, penyajian data, dan penarikan kesimpulan. Hasil penelitian menunjukkan bahwa dari masing-masing siswa yang bertipe kepribadian Keirsey dalam memecahkan masalah matematika lebih cenderung pada siswa yang bertipe kepribadian Guardian. dalam memecahkan masalah matematika di mulai dengan penerimaan informasi yang ditandai dengan memahami masalah meliputi mengetahui apa yang diketahui (M1), mengetahui apa yang ditanyakan (M2), mengetahui syarat-syarat yang diperlukan dalam pemecahan masalah (M3), serta membuat model maematika dari masalah dengan pengertian sendiri (M4). Kemudian dilanjutkan dengan pengolahan informasi yang ditandai dengan melaksanakan rencana penyelesaian dari masalah (R1) dan dilanjutkan dengan melaksanakan pelaksanaan rencana untuk mendapatkan jawaban (P1), namun langkah-langkahya kurang lengkap.
\end{abstract}


Sedangkan dalam pengecekan kembali jawaban (C1) siswa melakukan pengecekan kembali, kemudian dalam menarik kesimpulan (C2), siswa menarik kesimpulan hanya pada bagian tes. Kata Kunci : Proses berpikir matematis, Kepribadian Keirsey

\section{PENDAHULUAN}

Salah satu kompetensi yang harus dimiliki siswa dalam kurikulum matematika adalah kemampuan pemecahan masalah (Astuti, Budiyono, \& Usodo, 2014; Effendi, 2012; Fatmawati, Mardiyana, \& Triyanto, 2014; Hasanah, Mardiyana, \& Sutrima, 2013; Rohati, 2014; Widyastuti, 2015). Menurut beberapa ahli Pendidikan matematika, mengatakan masalah merupakan pertanyaan atau soal matematika yang harus dijawab atau direspon, tetapi tidak semua pertanyaan bahwa akan otomatis akan menjadi masalah. Karena bisa terjadi bahwa suatu masalah bagi seorang siswa akan menjadi pertanyaan bagi siswa lain karena ia sudah mengetahui langkah-langkah untuk menyelesaikannya (Fauziyah, Usodo, \& Ch., 2013; Hasanah et al., 2013). Melalui kegiatan pemecahan masalah, aspek-aspek yang penting dalam pembelajaran matematika dapat dikembangkan dengan baik.

Berdasarkan pra penelitian melaluli wawancara dengan seorang guru bidang studi matematika di MAN 2 Tulang Bawang Barat bernama Bapak Masagus Romli menyatakan bahwa pembelajaran matematika masih menggunakan pembelajaran yang bersifat konvensional, didominasi oleh kelas yang berfokus pada guru sebagai sumber belajar, dan siswa masih merasa pasif menerima apa yang disampaikan guru. Berangkat dari pembelajaran guru MAN 2 Tulang Bawang Barat, yang masih konvensional maka berdampak pada hasil belajar siswa pada materi statistika, banyak siswa yang mengalamai kesulitan memahami penyajian data dalam bentuk tabel, grafik maupun diagram dan masih banyak pula yang kesulitan dalam menyelesaikan soal-soal yang berkaitan dengan membuat tabel frekuensi, menentukan rata-rata, median, modus. Kebanyakan siswa bekerja kurang memperhatikan langkah-langkah penyelesaianya. Hanya sebagian kecil siswa yang berhasil menuntaskan belajarnya. Siswa hanya mementingkan hasil akhir jawabanya, sehingga banyak langkah-langkah yang tidak di tempuh padahal merupakan langkah yang menentukan hasil jawaban akhir.

Beberapa ahli menemukan beberapa cara dalam menyelesaikan masalah matematika, diantaranya adalah Polya. Langkah-langkah dalam memecahkan masalah menurut Polya diantaranya adalah analyzing and understanding a problem, designing and planning a solution, exploring solution to difficult problem, verifying a solution. Langkah pertama dalam pemecahan masalah matematika menurut Polya, yaitu analyzing and understanding a problem (menganalisis dan memahami masalah). Pada langkah ini, siswa harus dapat menganalisis dan memahami masalah yang ada dengan cara menetukan dan mencari apa yang diketahui dan apa yang ditanyakan pada masalah tersebut. Langkah kedua yaitu designing and planning a solution (merancang dan merencanakan solusi). Pada langkah ini, siswa harus dapat merancang dan merencanakan solusi yang ada berdasarkan apa yang 
telah diketahui dan ditanyakan pada masalah sesuai dengan langkah pertama. Langkah ke tiga yaitu exploring solution to difficult problem (mencari solusi dari masalah). Pada langkah ini, siswa harus menentukan solusi untuk dapat menyelesaikan permasalahan yang ada sesuai dengan rencana yang telah dibuat pada langkah kedua. Langkah ke empat yaitu verifying a solution (memeriksa solusi). Pada langkah ini siswa harus dapat memeriksa kembali hasil yang telah diperoleh, apakah jawabanya sudah benar dan sesuai dengan apa yang ditanyakan pada masalah atau belum (Fatmawati et al., 2014; Fitria \& Siswono, 2014; Rasiman, 2012; Widyastuti, 2015).

Adanya suatu masalah umumnya mendorong siswa untuk dapat memecahkan masalah dengan segera namun tidak tahu secara langsung bagaimana menyelesaikannya (Fatmawati et al., 2014). Saat memecahkan masalah, siswa melakukan proses berpikir dalam benak sehingga siswa dapat sampai pada jawaban. Sebagaimana menurut Herman Hudojo dalam (Argarini, Budiyono, \& Sujadi, 2014) menyatakan bahwa dengan pemecahan masalah individu akan berlatih memproses data atau informasi. Pemrosesan data atau informasi itu disebut berpikir. Sangat penting bagi guru untuk mengetahui proses berpikir siswa dalam menyelesaikan suatu masalah matematika sehingga guru dapat mengetahui jenis dan letak kesalahannya. Hasil pengamatan terhadap kondisi siswa diperoleh kesimpulan bahwa setiap siswa selalu mempunyai perbedaan. Perbedaan harus diterima dan dimanfaatkan dalam belajar. Kesalahan yang dilakukan siswa dapat dijadikan sumber informasi belajar dan pemahaman bagi siswa itu sendiri. Kesalahan yang dilakukan oleh siswa pasti sangat beragam, oleh karena itu proses berpikirnya pun pasti tidaklah sama (Hasanah et al., 2013). Penelitian tentang deskriptif kemampuan berpikir telah dilakukan oleh (Dodi et al., 2015; Rakhmawati, Rachmadiarti, \& Budiono, 2015; Retnowati, Sujadi, \& Subanti, 2016; Wijayanti, Pudjawan, \& Margunayasa, 2015). Hasil penelitian menyimpulkan bahwa siswa memiliki kemampuan berpikir dengan berbagai tingkatan, dan siswa rata-rata memiliki kemampuan berpikir tingkat rendah (Dodi, Hudiono, \& Suratman, 2015; Fatmawati et al., 2014).

Menurut Dewiyani dalam penelitiannya menunjukan hasil bahwa proses berpikir siswa berbeda-beda dilihat dari tipe kepribadian yang berbeda, selain itu perbedaan gender maka berbeda pula proses berpikirnya (Dewiyani, 2012). Pervin dalam (Lestudy, Imran, \& Yunitaningrum, 2013; Utaminingsih \& Setyabudi, 2012) menyatakan kepribadian diartikan sebagai karakteristik individu yang merupakan pola yang cenderung konsisten (tetap) mengenai perasaan, pikiran dan perilaku. Berpangkal pada kenyataan bahwa kepribadian manusia sangat bermacam-macam, bahkan mungkin sama banyak dengan banyaknya orang, segolongan ahli berusaha menggolong-golongkan manusia ke dalam tipe-tipe tertentu, karena mereka berpendapat bahwa cara itulah yang paling efektif untuk mengenal sesama manusia dengan baik. David Keirsey, seorang ahli bidang psikologi dari California State University, menggolongkan tipe kepribadian menjadi 4 tipe, yaitu: Guardian, Artisan, Rational, dan Idealist (Astuti et al., 2014; Aziz, Kusmayadi, \& Sujadi, 2014; Dewiyani, 2011; Hidayatulloh, Usodo, \& Riyadi, 2013). 
Penelitian proses berpikir dalam pemecahan masalah matematika ditinjau dari tipe kepribadian telah banyak dilakukan yaitu ditinjau dari tipe kepribadian Dimensi Myer-Briggs (Aziz et al., 2014), tipe kepribadian Extrovert-Introvert (Hasanah et al., 2013), tipe kepribadian choleris (Agustina, 2014), tipe kepribadian phlegmatis (Agustina \& Farida, 2015), ditinjau dari tipe kepribadian (sanguinis, koleris, melankolis, dan phlegmatis) (Fitria \& Siswono, 2014) dan tipe kepribadian influence (Rohati, 2014) serta tipe kepribadian thinking (Ramalisa, 2013). Penelitian telah juga dilakukan mengenai proses berpikir kreatif dalam memecahkan masalah ditinjau dari tipe kepribadian Kiersey (Hidayatulloh et al., 2013). Peneliti melakukan keterbaharuan dalam penelitian yaitu proses berpikir matematis dalam memecahkan masalah ditinjau dari tipe kepribadian Kiersey.

\section{METODOLOGI PENELITIAN}

Penelitian ini merupakan penelitian kualitatif-deskriptif. Data yang diperoleh pada penelitian ini berupa hasil wawancara yang dilakukan antara peneliti dengan siswa. Wawancara dilakukan pada saat siswa sudah menyelesaikan atau memecahkan masalah matematika berdasarkan tipe kepribadian. Teknik pengambilan sampel yang digunakan adalah purposive sampling. Pada penelitian ini subyek yang digunakan adalah 8 orang siswa kelas XI program ilmu alam MAN 2 Tulang Bawang Barat semester genap tahun ajaran 2015/2016. Delapan siswa tersebut terdiri dari 2 orang siswa bertipe kepribadian Guardian, 2 orang siswa bertipe kepribadian Artisan, 2 orang siswa bertipe kepribadian Rational, dan 2 orang siswa bertipe kepribadian Idealis. Alasan memilih siswa kelas XI sebagai subyek penelitian, siswa kelas XI sudah memiliki pengalaman belajar yang cukup, sehingga diharapkan dapat menyelesaikan soal-soal tentang pemecahan masalah, jumlah jam pelajaran matematika pada kelas XI ilmu alam lebih banyak di banding dengan kelas XI ilmu sosial, dan lebih mudah diwawancarai untuk memperoleh data akurat yang dubutuhkan pada penelitian ini.

Sebelum menentukan subyek penelitian, peneliti terlebih dahulu menyiapkan tes penggolongan tipe kepribadian yang dibuat oleh David Keirey. Peneliti menggunakan satu kelas untuk memberikan tes penggolongan tipe kepribadian Keirsey. Dari hasil tes tersebut dipilih 2 orang siswa tipe kepribadian Guardian, 2 orang siswa tipe kepribadian Artisan, 2 orang siswa tipe kepribadian Rational, dan 2 orang siswa tipe kepribadian Idealis. Dengan meminta pertimbangan dari guru. Pertimbangan tersebut terkait dengan salah satu kriteria penentuan subyek yaitu dipilih siswa yang dapat mengungkapkan secara bagus.

Soal tes penggolongan tipe kepribadian menggunakan The Keirsey Temperament Sorter (KTS) yang dibuat oleh David Keirsey. Soal tesebut menggunakan bahasa Inggris sehingga harus di terjemahkan dalam bahasa Indonesia untuk mempermudah siswa dalam mengerjakan dan memahami tes tersebut. Teknik pengumpulan data menggunakan wawancara, dokumentasi, dan observasi. Proses analisis data menggunakan model Miles dan Huberman, yaitu reduksi data, penyajian data, dan penarikan kesimpulan. Uji keabsahan 
data dalam penelitian ini peneliti menggunakan triangulasi teknik, yang berarti peneliti menggunakan pengumpulan data yang berbeda-beda untuk mendapatkan data dari sumber yang sama. Peneliti menggunakan tes soal pemecahan masalah dan wawancara untuk mendapatkan data dari sumber yang sama.

\section{HASIL PENELITIAN DAN PEMBAHASAN}

Berdasarkan analisis data yang telah dilakukan diatas dapat dilihat bahwa pada masalah yang pertama meliputi menganalisis dan memahami masalah, merancang dan merencanakan solusi, mencari solusi dari masalah, memeriksa solusi berikut rangkuman hasil proses berpikir siswa pada masalah pertama. Kode " $\mathrm{P}$ " berarti Peneliti. Kode "G.2" berarti Guardian pertama. Kode "G.3" berarti Guardian ketiga. Kode "A.1" berarti Artisan pertama. Kode "A.3" berarti Artisan ketiga. Kode "I.1" berarti Idelaist pertama

Tabel 1. Rangkuman Hasil Proses Berpikir Siswa pada Masalah Pertama

\begin{tabular}{|c|c|c|c|c|}
\hline $\begin{array}{c}\text { Tipe } \\
\text { Kepribadian } \\
\text { Siswa }\end{array}$ & $\begin{array}{l}\text { Menganalisis } \\
\text { Dan } \\
\text { Memahami } \\
\text { Masalah }\end{array}$ & $\begin{array}{c}\text { Proses Berpikir Yan } \\
\text { Merancang } \\
\text { Dan } \\
\text { Merencanakan solusi }\end{array}$ & $\begin{array}{l}\text { Mencari solusi } \\
\text { Dari masalah }\end{array}$ & $\begin{array}{c}\text { Memeriksa } \\
\text { Solusi }\end{array}$ \\
\hline G.2 & $\begin{array}{l}\text { Dapat membaca } \\
\text { masalah secara } \\
\text { keseluruhan }\end{array}$ & $\begin{array}{l}\text { 1. Pada saat } \\
\text { menyusun } \\
\text { perencanaan } \\
\text { masalah subjek G.2 } \\
\text { mengaitkan dan } \\
\text { menyebutkan } \\
\text { beberapa yang ia } \\
\text { ketahui tentang } \\
\text { cara membuat } \\
\text { tabel idstribusi } \\
\text { frekuensi } \\
\text { 2. Dapat menentukan } \\
\text { rumus tepi atas } \\
\text { dan tepi bawah } \\
\text { kelas yang subjek } \\
\text { ketahui }\end{array}$ & $\begin{array}{l}\text { 1. Dapat } \\
\text { mengguakan } \\
\text { rencana } \\
\text { pemecahan } \\
\text { masalah dari } \\
\text { awal yaitu } \\
\text { dapat } \\
\text { meyebutkan } \\
\text { dengan benar } \\
\text { yang diketahui } \\
\text { dan apa yang } \\
\text { ditanyakan } \\
\text { dari masalah. } \\
\text { 2. Belum dapat } \\
\text { menyelesaikan } \\
\text { masalah } \\
\text { berdasarkan } \\
\text { langkah- } \\
\text { langkah } \\
\text { pemecahan } \\
\text { masalah yang }\end{array}$ & $\begin{array}{l}\text { 1. Tidak } \\
\text { memeriks } \\
\text { a jawaban } \\
\text { 2. Tidak } \\
\text { menuliskan } \\
\text { apa yang } \\
\text { telah } \\
\text { dikerjakan } \\
\text { pada } \\
\text { proses ini. }\end{array}$ \\
\hline
\end{tabular}




\begin{tabular}{|c|c|c|c|c|}
\hline \multirow[b]{2}{*}{$\begin{array}{c}\text { Tipe } \\
\text { Kepribadian } \\
\text { Siswa }\end{array}$} & \multicolumn{4}{|c|}{ Proses Berpikir Yang Digunakan } \\
\hline & $\begin{array}{l}\text { Menganalisis } \\
\text { Dan } \\
\text { Memahami } \\
\text { Masalah }\end{array}$ & $\begin{array}{c}\text { Merancang } \\
\text { Dan } \\
\text { Merencanakan solusi }\end{array}$ & $\begin{array}{l}\text { Mencari solusi } \\
\text { Dari masalah }\end{array}$ & $\begin{array}{c}\text { Memeriksa } \\
\text { Solusi }\end{array}$ \\
\hline & & & $\begin{array}{l}\text { telah disusun. } \\
\text { (membuat } \\
\text { tabel distribusi } \\
\text { frekuensi } \\
\text { dengan } \\
\text { langkah- } \\
\text { langkah } \\
\text { menentukan } \\
\text { range, banyak } \\
\text { kelas, panjang } \\
\text { kelas, batas } \\
\text { atas kelas dan } \\
\text { batas bawah } \\
\text { kelas lalu } \\
\text { membuat } \\
\text { tabel). }\end{array}$ & \\
\hline G.3 & $\begin{array}{l}\text { 1. Dapat dengan } \\
\text { mudah } \\
\text { menyebutkan } \\
\text { apa yang } \\
\text { diketahui apa } \\
\text { yang } \\
\text { ditanyakan } \\
\text { dari masalah }\end{array}$ & $\begin{array}{l}\text { 1. Pada saat menyusun } \\
\text { perencanaan } \\
\text { masalah subjek G.3 } \\
\text { mengaitkan } \\
\text { pengetahuan yang } \\
\text { telah diketahui } \\
\text { untuk } \\
\text { menyempurnakan } \\
\text { tabel ditribusi } \\
\text { frekuensi. }\end{array}$ & $\begin{array}{l}\text { 1. Tidak dapat } \\
\text { menyelesaiak } \\
\text { an masalah } \\
\text { berdasarkan } \\
\text { langkah- } \\
\text { langkah } \\
\text { pemecahan } \\
\text { masalah yag } \\
\text { telah disusun } \\
\text { (siswa hanya } \\
\text { memuat tabel } \\
\text { ditribusi } \\
\text { frekuensi } \\
\text { dengan } \\
\text { sepengetahua } \\
\text { n siswa saja, } \\
\text { sehingga } \\
\text { jawaban yang }\end{array}$ & $\begin{array}{l}1 \text { memeriksa } \\
\text { kembali } \\
\text { jawaban } \\
\text { yang telah } \\
\text { diperoleh. } \\
2 \text { meyakini } \\
\text { jawaban } \\
\text { yang telah } \\
\text { diperoleh } \\
\text { sehingga } \\
\text { siswa tidak } \\
\text { mengganti } \\
\text { jawabanya } \\
\text {. }\end{array}$ \\
\hline
\end{tabular}




\begin{tabular}{|c|c|c|c|c|}
\hline $\begin{array}{c}\text { Tipe } \\
\text { Kepribadian } \\
\text { Siswa }\end{array}$ & $\begin{array}{l}\text { Menganalisis } \\
\text { Dan } \\
\text { Memahami } \\
\text { Masalah }\end{array}$ & $\begin{array}{c}\text { Proses Berpikir Yan } \\
\text { Merancang } \\
\text { Dan } \\
\text { Merencanakan solusi }\end{array}$ & $\begin{array}{c}\text { Mencari solusi } \\
\text { Dari masalah }\end{array}$ & $\begin{array}{c}\text { Memeriksa } \\
\text { Solusi }\end{array}$ \\
\hline A.1 & $\begin{array}{l}\text { 1. Dapat dengan } \\
\text { mudah } \\
\text { mebaca } \\
\text { masalah } \\
\text { secara } \\
\text { keseluruhan } \\
\text { 2. Dapat dan } \\
\text { mudah } \\
\text { menyebutkan } \\
\text { apa yang } \\
\text { diketahui } \\
\text { pada masalah } \\
\text { dan } \\
\text { menyebutkan } \\
\text { apa yang } \\
\text { ditanyakan. }\end{array}$ & $\begin{array}{l}\text { 1. Pada saat } \\
\text { menyususn } \\
\text { perencanaan } \\
\text { masalah, subjek A.1 } \\
\text { tidak dapat } \\
\text { mengaitkan apa } \\
\text { yang diketahui } \\
\text { dengan apa yang } \\
\text { ditanyakan } \\
\text { 2. Tidak dapat mebuat } \\
\text { tabel ditribusi } \\
\text { frekuensi }\end{array}$ & $\begin{array}{l}\text { peroleh } \\
\text { belum tepat.) } \\
\text { 1. Belum dapat } \\
\text { menjewab } \\
\text { masalah } \\
\text { berdasarkan } \\
\text { langkah- } \\
\text { langkah } \\
\text { pemecahan } \\
\text { masalah yang } \\
\text { telah disusun } \\
\text { dan jawaban } \\
\text { yang } \\
\text { diperoleh } \\
\text { belum tepat. }\end{array}$ & $\begin{array}{l}\text { 1. Tidak } \\
\text { memeriksa } \\
\text { solusi } \\
\text { langkah } \\
\text { demi } \\
\text { langkah } \\
\text { pekerjaan } \\
\text { yang telah } \\
\text { dibuat. } \\
\text { Hanya } \\
\text { mebuat } \\
\text { coret- } \\
\text { coretan } \\
\text { pada } \\
\text { kertas. }\end{array}$ \\
\hline A. 3 & $\begin{array}{l}\text { 1. Dapat } \\
\text { menyebutkan } \\
\text { apa yang } \\
\text { diketahui apa } \\
\text { yang } \\
\text { ditanyakan } \\
\text { dari masalah }\end{array}$ & $\begin{array}{l}\text { 1. Pada saat } \\
\text { menyususn } \\
\text { perencanaan } \\
\text { masalah, subjek A.3 } \\
\text { tidak dapat } \\
\text { mengaitkan apa } \\
\text { yang diketahui } \\
\text { dengan apa yang } \\
\text { ditanyakan } \\
\text { 2. Tidak dapat } \\
\text { mebuat tabel } \\
\text { ditribusi frekuensi }\end{array}$ & $\begin{array}{l}\text { 1. Belum dapat } \\
\text { menjewab } \\
\text { masalah } \\
\text { berdasarkan } \\
\text { langkah- } \\
\text { langkah } \\
\text { pemecahan } \\
\text { masalah yang } \\
\text { telah disusun } \\
\text { dan jawaban } \\
\text { yang } \\
\text { diperoleh } \\
\text { belum tepat. }\end{array}$ & $\begin{array}{l}\text { 1. Tidak } \\
\text { memeriksa } \\
\text { solusi } \\
\text { langkah } \\
\text { demi } \\
\text { langkah } \\
\text { pekerjaan } \\
\text { yang telah } \\
\text { dibuat. }\end{array}$ \\
\hline
\end{tabular}




\begin{tabular}{|c|c|c|c|c|}
\hline $\begin{array}{c}\text { Tipe } \\
\text { Kepribadian } \\
\text { Siswa }\end{array}$ & $\begin{array}{c}\text { Menganalisis } \\
\text { Dan } \\
\text { Memahami } \\
\text { Masalah }\end{array}$ & $\begin{array}{c}\text { Proses Berpikir Yang } \\
\text { Merancang } \\
\text { Dan } \\
\text { Merencanakan solusi }\end{array}$ & $\begin{array}{l}\text { Mencari solusi } \\
\text { Dari masalah }\end{array}$ & $\begin{array}{c}\text { Memeriksa } \\
\text { Solusi }\end{array}$ \\
\hline & $\begin{array}{l}\text { mebaca } \\
\text { masalah } \\
\text { secara } \\
\text { keseluruhan } \\
\text { 2. Dapat dan } \\
\text { mudah } \\
\text { menyebutkan } \\
\text { apa yang } \\
\text { diketahui } \\
\text { pada masalah } \\
\text { dan } \\
\text { menyebutkan } \\
\text { apa yang } \\
\text { ditanyakan. }\end{array}$ & $\begin{array}{l}\text { masalah subjek I.1 } \\
\text { mengaitkan dan } \\
\text { menyebutkan } \\
\text { beberapa yang ia } \\
\text { ketahui tentang cara } \\
\text { membuat tabel } \\
\text { distribusi frekuensi. } \\
\text { 2. Dapat membuat } \\
\text { tabel distribusi } \\
\text { frekuensi sesuai } \\
\text { kemampuan siswa }\end{array}$ & $\begin{array}{l}\text { masalah } \\
\text { sesuai dengan } \\
\text { langkah- } \\
\text { langkah } \\
\text { pemecahan } \\
\text { masalah yang } \\
\text { telah disusun } \\
\text { dan tabel } \\
\text { ditribusi yang } \\
\text { dilakukan } \\
\text { belum tepat. }\end{array}$ & $\begin{array}{l}\text { solusi } \\
\text { langkah } \\
\text { demi } \\
\text { langkah } \\
\text { pekerjaan } \\
\text { yang telah } \\
\text { dibuat. }\end{array}$ \\
\hline
\end{tabular}

Berdasarkan analisis data yang telah dilakukan di atas dapat dilihat bahwa pada masalah yang pertama meliputi menganalisis dan memahami masalah, merancang dan merencanakan solusi, mencari solusi dari masalah, memeriksa solusi berikut rangkuman hasil proses berpikir siswa pada masalah kedua:

Tabel 2. Rangkuman Hasil Proses Berpikir Siswa Pada Masalah Kedua

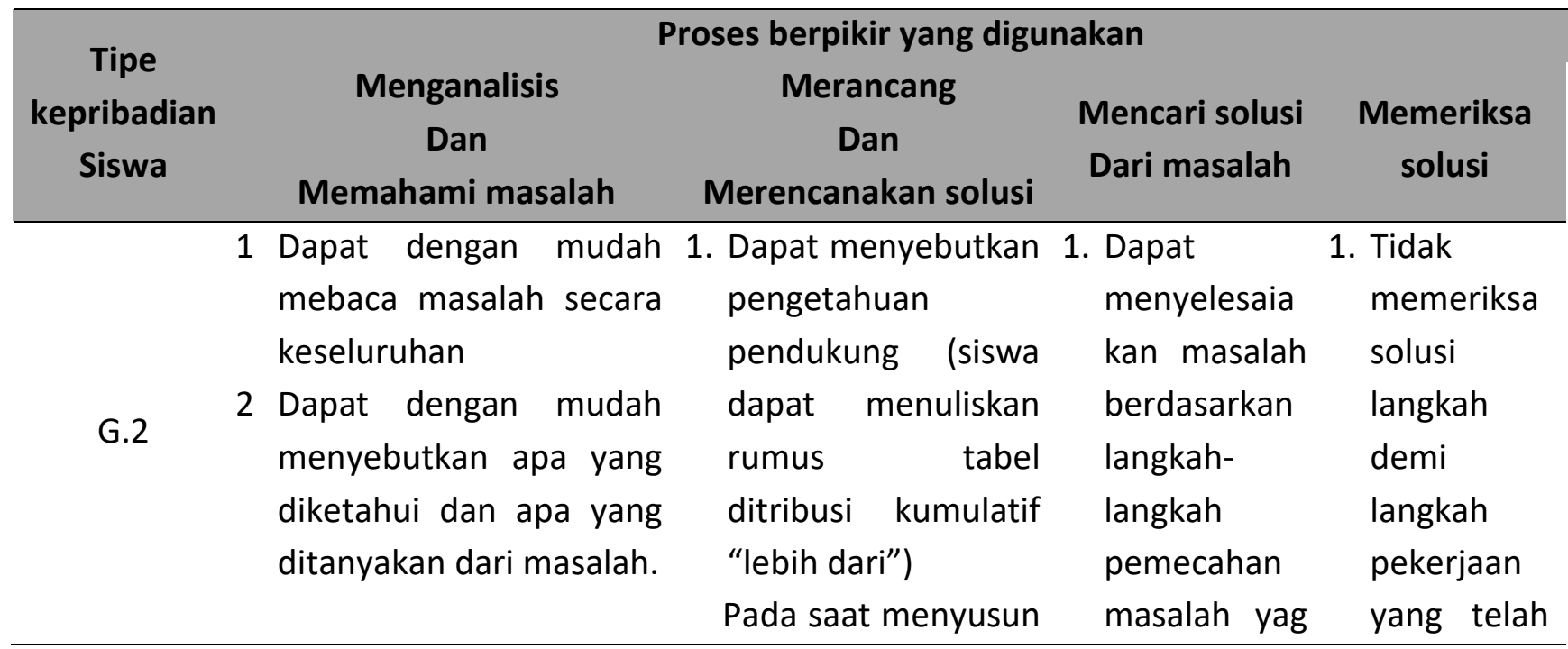




\begin{tabular}{|c|c|c|c|c|}
\hline \multirow[b]{2}{*}{$\begin{array}{c}\text { Tipe } \\
\text { kepribadian } \\
\text { Siswa }\end{array}$} & \multicolumn{4}{|c|}{ Proses berpikir yang digunakan } \\
\hline & $\begin{array}{c}\text { Menganalisis } \\
\text { Dan } \\
\text { Memahami masalah }\end{array}$ & $\begin{array}{l}\text { Merancang } \\
\text { Dan } \\
\text { Merencanakan solusi }\end{array}$ & $\begin{array}{l}\text { Mencari solusi } \\
\text { Dari masalah }\end{array}$ & $\begin{array}{c}\text { Memeriksa } \\
\text { solusi }\end{array}$ \\
\hline & & $\begin{array}{l}\text { perencanaan } \\
\text { masalah subjek } \mathrm{G} .2 \\
\text { mengaitkan } \\
\text { pengetahuan yang } \\
\text { telah diketahui } \\
\text { untuk } \\
\text { menyempurnakan } \\
\text { tabel ditribusi } \\
\text { frekuensi. }\end{array}$ & $\begin{array}{l}\text { telah disusun } \\
\text { (siswa hanya } \\
\text { membuat } \\
\text { tabel } \\
\text { frekuensi } \\
\text { kumulatif } \\
\text { "lebih dari". } \\
\text { da ogive } \\
\text { positif. meki } \\
\text { jawaban } \\
\text { yang } \\
\text { diperoleh } \\
\text { belum } \\
\text { tepat). }\end{array}$ & $\begin{array}{l}\text { dibuat. } \\
\text { Hanya } \\
\text { mebuat } \\
\text { coret- } \\
\text { coretan } \\
\text { pada } \\
\text { kertas. }\end{array}$ \\
\hline A.1 & $\begin{array}{l}\text { 1. Dapat dengan mudah } \\
\text { mebaca masalah secara } \\
\text { keseluruhan } \\
\text { 2. Dapat dan mudah } \\
\text { menyebutkan apa yang } \\
\text { diketahui pada masalah } \\
\text { dan menyebutkan apa } \\
\text { yang ditanyakan. }\end{array}$ & $\begin{array}{l}\text { 1. Pada saat } \\
\text { menyususn } \\
\text { perencanaan } \\
\text { masalah, subjek A.1 } \\
\text { tidak dapat } \\
\text { mengaitkan apa } \\
\text { yang diketahui } \\
\text { dengan apa yang } \\
\text { ditanyakan } \\
\text { 2. Tidak dapat mebuat } \\
\text { tabel ditribusi } \\
\text { frekuensi }\end{array}$ & $\begin{array}{l}\text { 1. Belum dapat } \\
\text { menjewab } \\
\text { masalah } \\
\text { berdasarkan } \\
\text { langkah- } \\
\text { langkah } \\
\text { pemecahan } \\
\text { masalah } \\
\text { yang telah } \\
\text { disusun dan } \\
\text { jawaban } \\
\text { yang } \\
\text { diperoleh } \\
\text { belum tepat. }\end{array}$ & $\begin{array}{l}\text { 1. Tidak } \\
\text { memeriksa } \\
\text { solusi } \\
\text { langkah } \\
\text { demi } \\
\text { langkah } \\
\text { pekerjaan } \\
\text { yang telah } \\
\text { dibuat. } \\
\text { Hanya } \\
\text { mebuat } \\
\text { coret- } \\
\text { coretan } \\
\text { pada } \\
\text { kertas. }\end{array}$ \\
\hline A.3 & $\begin{array}{l}\text { 1. Dapat menyebutkan apa } \\
\text { yang diketahui apa yang } \\
\text { ditanyakan dari masalah }\end{array}$ & $\begin{array}{l}1 \text { Pada saat } \\
\text { menyususn } \\
\text { perencanaan } \\
\text { masalah, subjek A.3 } \\
\text { tidak dapat } \\
\text { mengaitkan apa }\end{array}$ & $\begin{array}{l}\text { 1. Belum dapat } \\
\text { menjewab } \\
\text { masalah } \\
\text { berdasarkan } \\
\text { langkah- } \\
\text { langkah }\end{array}$ & $\begin{array}{l}\text { 1. Tidak } \\
\text { memeriksa } \\
\text { solusi } \\
\text { langkah } \\
\text { demi } \\
\text { langkah }\end{array}$ \\
\hline
\end{tabular}




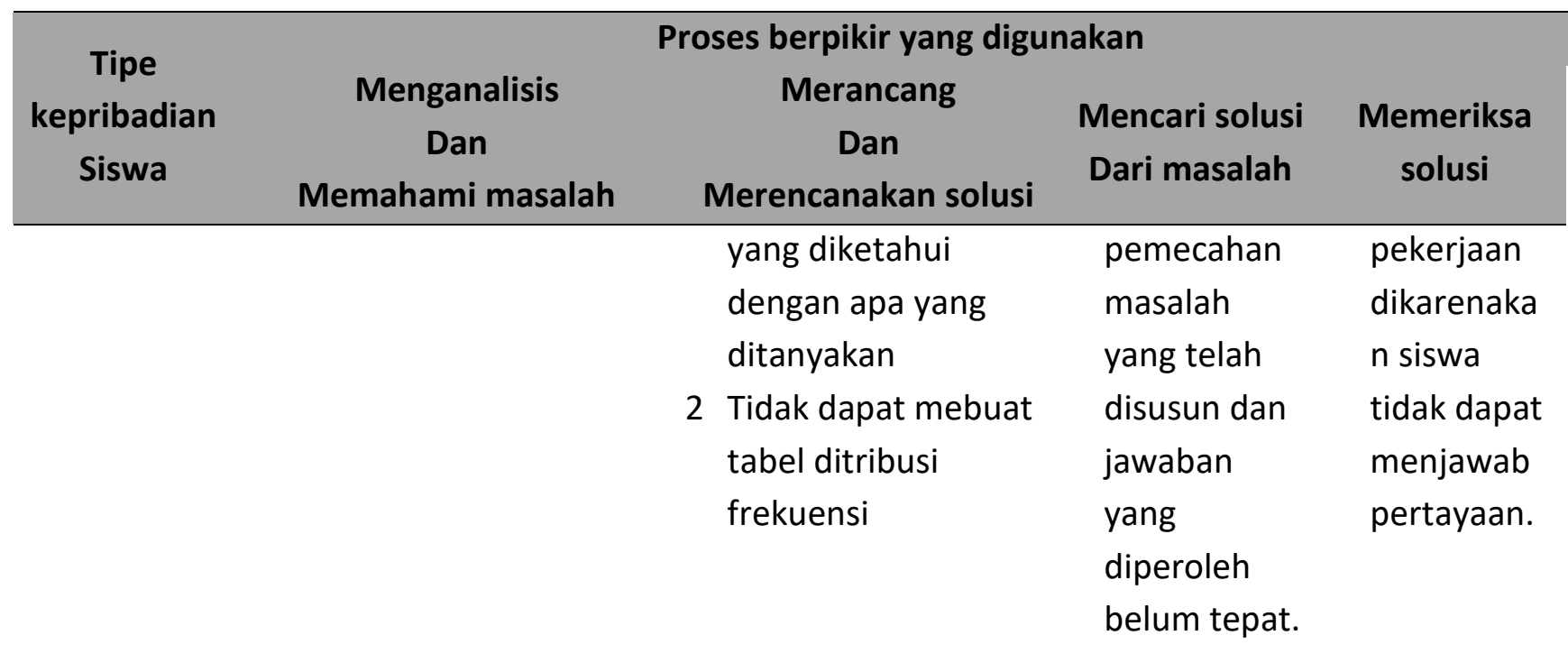

Berdasarkan analisis data yang telah dilakukan di atas dapat dilihat bahwa pada masalah yang pertama meliputi menganalisis dan memahami masalah, merancang dan merencanakan solusi, mencari solusi dari masalah, memeriksa solusi berikut rangkuman hasil proses berpikir siswa pada masalah ketiga:

Tabel 3. Rangkuman Hasil Proses Berpikir Siswa Pada Masalah Ketiga

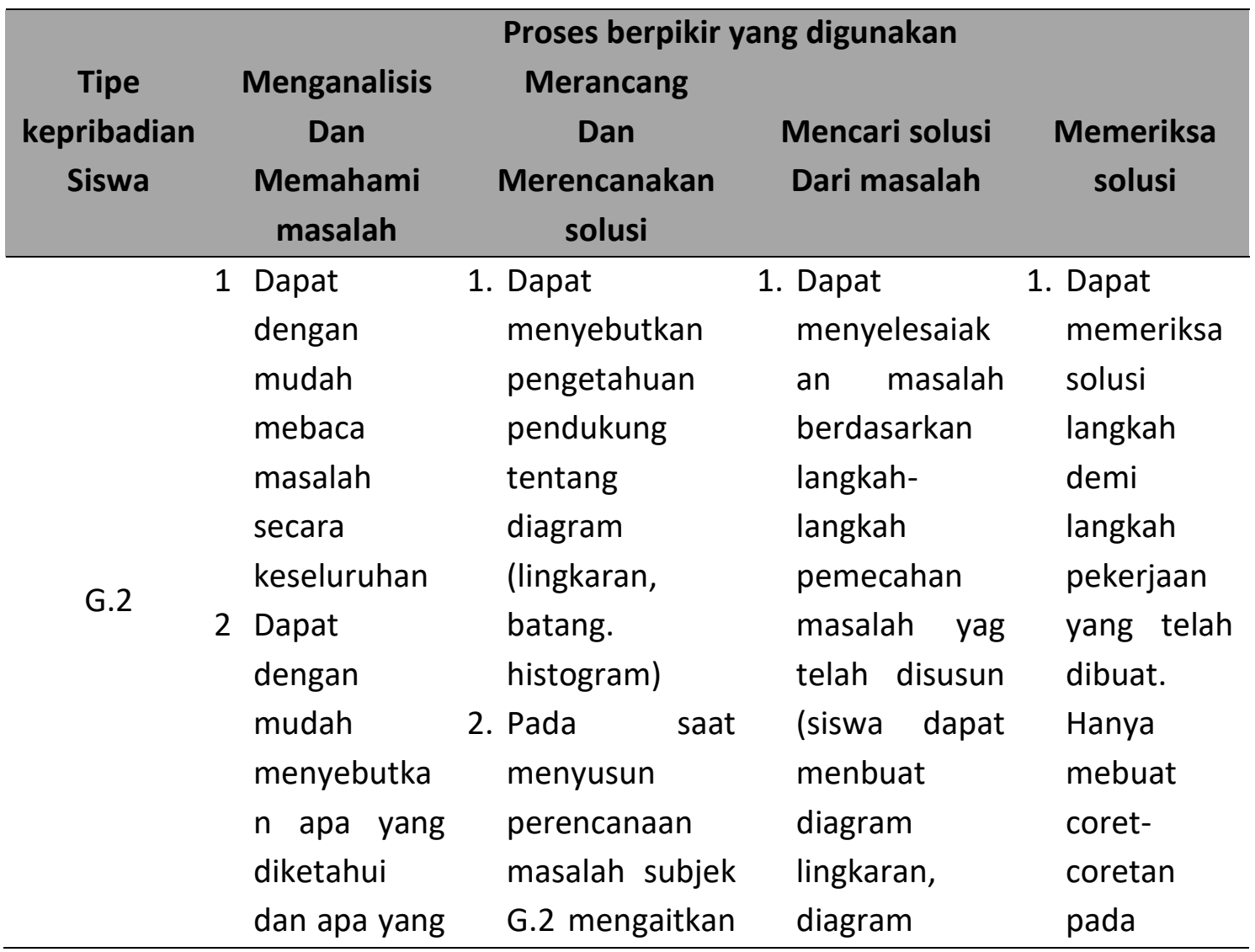




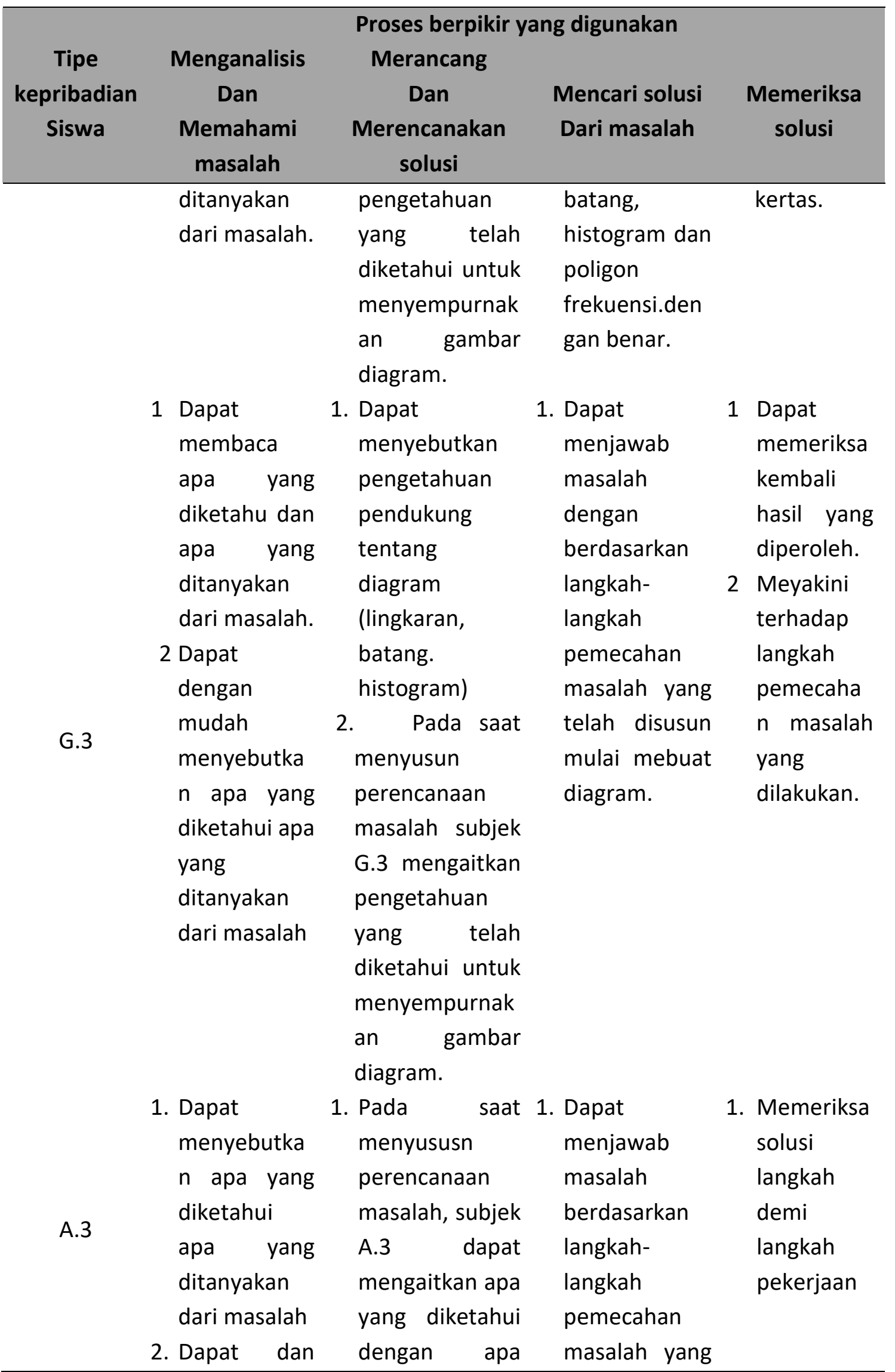




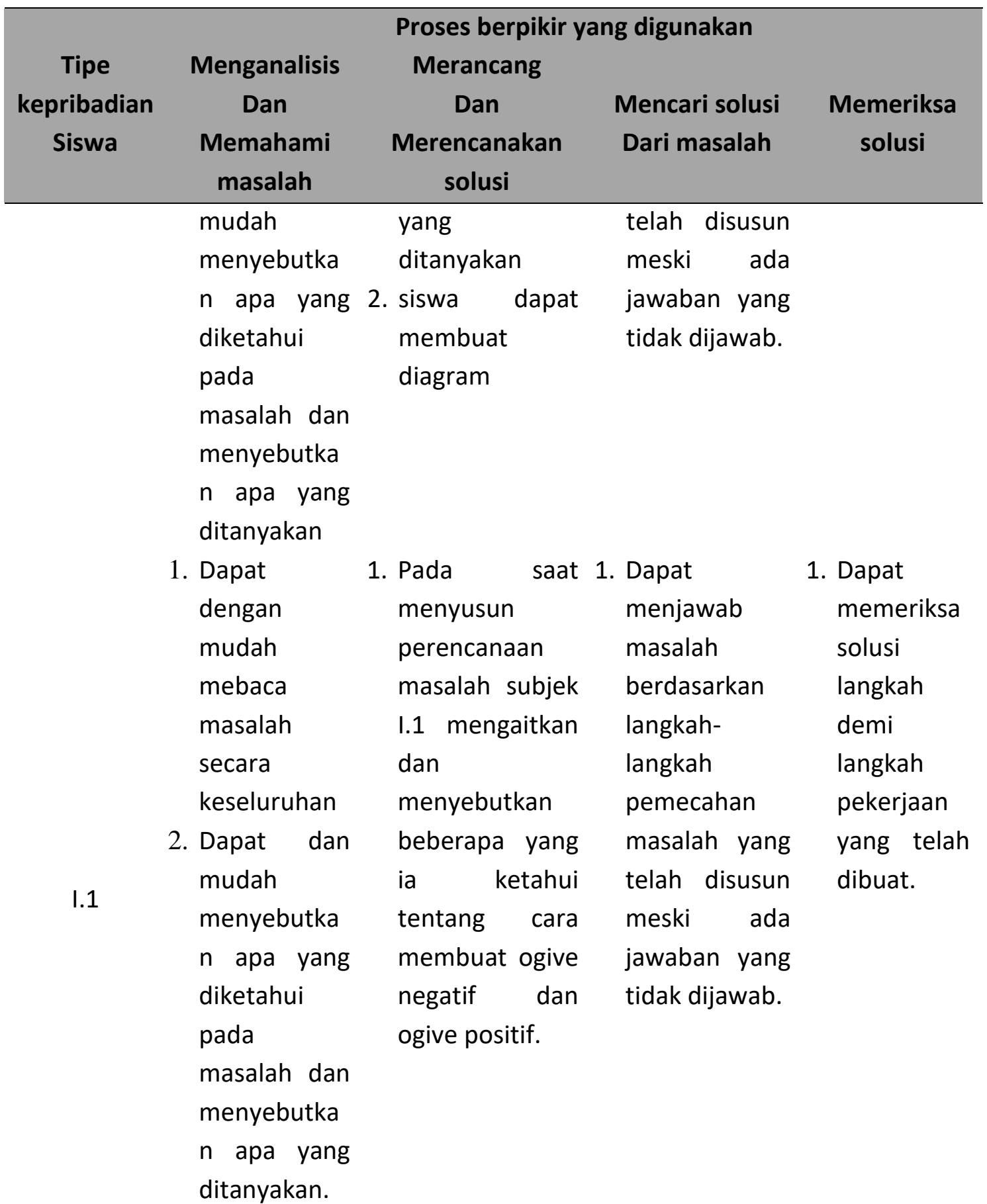

Berdasarkan tabel di atas diketahui bahwa pengambilan data menggunakan dua teknik yang berbeda yaitu teknik observasi dan teknik wawancara, tidak ditemukan perbedaan data yang diperoleh, yaitu untuk memahami masalah siswa tidak merasa kesulitan dalam memahami masalah siswa dapat menentukan apa yang diketuhi dan apa yang ditanyakan dari soal. Meskipun terdapat sedikit kesulitan untuk memahami masalah nomor satu, akhirnya siswa dapat memahami masalah dengan cara membaca sola secara berulang-ulang. 
Analisis proses berpikir siswa Guardian dalam memecahkan masalah matematika mengacu pada langkah-langkah Polya, dimulai dari proses berpikir siswa dalam memahami masalah, menyusun recana penyelesaian, menyelesaikan masalah sesuai perencanaan, sampai memeriksa kembali hasil yang telah diperoleh. Berdasarkan hasil analisis data diperoleh hasil bahwa siswa Guardian dalam memahami masalah baik pada masalah pertama, kedua, dan ketiga siswa dapat secara langsung mengidentifikasi hal-hal yang diketahui dan hal yang ditanyakan pada masalah dengan lancar dan benar. Siswa tidak memerlukan informasi lain untuk bisa menyelesaikan masalah selain hal yang diketahui pada masalah dan siswa menggunakan semua hal yang diketahui untuk bisa menyelesaikan masalah tersebut. dengan demikian dapat dikatakan bahwa siswa dapat memahami masalah.

Hasil analisis data berikutnya adalah siswa Guardian menyusun rencana penyelesaian, baik pada masalah pertama sampai ketiga. dalam menyusun rencana penyelesaian, siswa dapat menentukan dengan lancar langkah apa saja yang digunakan untuk bisa menyelesaikan masalah kecuali pada masalah nomor satu, pada soal nomor satu siswa tidak dapat menyusun rencana penyelesaian. Siswa kesulitan menentukan langkah-langkah membuat tabel distribusi frekuensi. Sehingga siswa memutuskan untuk tidak menuliskan jawaban. Dalam menyusun rencana penyelesaian pada masalah nomor dua siswa Guardian tidak keseluruhan dalam menuliskan langkah penyelesaianya sedang pada masalah nomor tiga siswa Guardian dapat menelesaikan masalah dengan benar. dengan demikin dapat dikatakan bahwa siswa Guardian dapat menyelesaikan masalah dengan perencanaan.

Analisis proses berpikir yang dilakukan siswa Artisan dalam memecahkan masalah matematika mengacu pada langkah-langkah polya. Berdasarkan hasil analisis data diperoleh hasil bahwa siswa Artisan dalam memahami masalah baik pada masalah pertama maupun masalah ketiga, siswa dapat secara langsung mengidentifikasi hal-hal yang diketahui dan hal yang ditanya pada masalah dengan lancar dan benar, baik pada masalah pertama maupun masalah ketiga. siswa tidak memerlukan informasi lain untuk dapat menyelesaikan masalah selain hal-hal yang telah diketahui pada masalah dan siswa menggunakan semua hal yang diketahui untuk menyelesaikan masalah tersebut. dengan demikian dapat dikatakan bahwa siswa dapat menganalisis dan memahami masalah.

Hasil analisis data selanjutnya adalah siswa Artisan dalam menyusun rencana penyelesaian, pada masalah pertama dan kedua siswa Artisan baik A.1 dan A.2 tidak dapat menentukan langkah apa saja yang akan digunakan untuk menyelesaikan masalah dengan lancar dan benar. siswa tidak dapat menyebutkan apa saja langkah-langkah yang akan digunakan sehingga siswa tidak mendapatkan jawaban yang benar. siswa merasa kesulitan untuk menentukan langkah penyelesaian masalah. sedangkan pada masalah ke tiga siswa A.1 dan A.2 dapat menentukan langkah apa yang akan digunakan dalam menyelesaikan masalah ketiga, namun sedikit kurang lancar. 
Analisis proses berpikir yang dilakukan siswa Idealist dalam memecahkan masalah matematika mengacu pada langkah-langkah polya. Berdasarkan hasil analisis data diperoleh hasil bahwa siswa Idealist dalam memahami masalah baik pada masalah pertama maupun masalah ketiga, siswa dapat secara langsung mengidentifikasi hal-hal yang diketahui dan hal yang ditanya pada masalah dengan lancar dan benar, baik pada masalah pertama maupun masalah ketiga. Siswa tidak memerlukan informasi lain untuk dapat menyelesaikan masalah selain hal-hal yang telah diketahui pada masalah dan siswa menggunakan semua hal yang diketahui untuk menyelesaikan masalah tersebut. dengan demikian dapat dikatakan bahwa siswa dapat menganalisis dan memahami masalah.

Hasil analisis data selanjutnya adalah siswa Idealist dalam menyusun rencana penyelesaian, pada masalah pertama siswa Idealist tidak dapat menentukan langkah apa saja yang akan digunakan untuk menyelesaikan masalah dengan lancar dan benar. Siswa tidak dapat menyebutkan apa saja langkah-langkah yang akan digunakan sehingga siswa tidak mendapatkan jawaban yang benar. Siswa merasa kesulitan untuk menentukan langkah penyelesaian masalah. Sedangkan pada masalah nomor dua dan tiga, siswa Idealist dapat menentukan langkah apa yang akan digunakan dalam menyelesaikan masalah ketiga, namun sedikit kurang lancar. dengan demikian dapat dikatakan bahwa siswa Idealist dapat menyusun rencana penyelesaian.

Pemeriksaan kembali hasil yang telah diperoleh, siswa Idealist baik pada masalah pertama maupun kedua dan ketiga. siswa dapat meyakini kebenaran dari hasil yang telah diperoleh, pada masalah ketiga. siswa dapat menentukan dengan lancar dan benar cara memeriksa kembali hasil yang telah diperolehnya, yaitu dengan melihat kesesuaian antara hasil yang telah diperoleh dengan yang diketahui pada masalah. dengan demikian dapat dikatakan bahwa siswa Idealist melakukan proses berpikir dalam memeriksa kembali hasil yang telah diperoleh.

Berdasarkan dari hasil wawancara terlihat bahwa selama siswa menyelesaikan masalah, siswa tidak pernah mengeluh terhadap maslaah yang diberikan. jika siswa mengalami keraguan dalam menyelesaikan masalah, siswa tidak pernah putus asa dan selalu berusaha untuk bisa menyelesaikan masalah, siswa tidak pernah putus asa dan berusaha untuk bisa menyelesaikan masalah tersebut sehingga mendapatkan hasil yang baik. Siswa tidak begitu saja percaya.

Hal ini sesuai dengan teori Keirsey yang mengatakan bahwa orang dengan tipe kepribadian Guardian adalah tipe orang yang konservatif kurang menyenangi perubahan, kurang menyenangi hal yang baru, pandai dalam memimpin, teliti, memiliki ingatan yang kuat, mengerjakan sesuatu tepat waktu, menyukai pengulangan dan drill dalam menerima materi. Lain dengan seseorang yang bertipe kepribadian Artisan, orang yang bertipe kepribadian Artisan adalah tipe orang yang senang bertindak sebelum berfikir, mengikuti kata hati, melakukan sesuatu ketika mendesak, seslalu ingin menjadi perhatian, cenderung 
tergesa-gesa, cepat bosan. Sedangkan tipe Idealist adalah tipe orang yang pengamat yang tajam, lebih suka menyelesaikan tugas secara pribadi (Hidayatulloh et al., 2013).

Sejalan juga dengan hasil penelitian oleh (Hidayatulloh et al., 2013) bahwa Subjek bertipe kepribadian guardian dan idealist memiliki proses berpikir kreatif tingkat 3 (kreatif). Proses berpikir kreatif tingkat 1 (kurang kreatif) dimiliki subjek bertipe kepribadian rational. Subjek bertipe kepribadian artisan memiliki proses berpikir kreatif tingkat 0 (tidak kreatif). Hasil penelitian ini juga didukung oleh (Dewiyani, 2012; Fitria \& Siswono, 2014) yang menyimpulkan bahwa setiap tipe kepribadian mempunyai keterampilan berpikir yang berbeda-beda dalam memecahkan masalah. Perbedaan tersebut terlihat pada saat memahami informasi yang terdapat pada soal.

\section{SIMPULAN DAN SARAN}

Berdasarkan hasil pembahasan maka proses berpikir matematis siswa yang lebih dominan adalah siswa yang bertipe kepribadian Guardian, dalam memecahkan masalah matematika di mulai dengan penerimaan informasi yang ditandai dengan memahami masalah meliputi mengetahui apa yang diketahui (M1), mengetahui apa yang ditanyakan (M2), mengetahui syarat-syarat yang diperlukan dalam pemecahan masalah (M3), serta membuat model maematika dari masalah dengan pengertian sendiri (M4). Kemudian dilanjutkan dengan pengolahan informasi yang ditandai dengan melaksanakan rencana penyelesaian dari masalah (R1) dan dilanjutkan dengan melaksanakan pelaksanaan rencana untuk mendapatkan jawaban (P1), namun langkah-langkahya kurang lengkap. Sedangkan dalam pengecekan kembali jawaban (C1) siswa melakukan pengecekan kembali, kemudian dalam menarik kesimpulan (C2), siswa menarik kesimpulan hanya pada sebagian tes.

Berdasarkan kesimpulan pada penelitian ini, pembelajaran pemecahan masalah matematika berdasarkan langkah-langkah Polya disarankan kepada guru matematika untuk harus dapat memberikan motovasi dan perhatian yang lebih kepada siswa yang bertipe kepribadian berbeda-beda pada saat siswa dihadapkan dengan soal matematika dalam bentuk pemecahan masalah, guru harus membiasakan siswa untuk dapat menyelesaikan masalah dengan menggunakan langkah-langkah Polya untuk mempermudah siswa dalam menyelesaikan masalah.

\section{DAFTAR PUSTAKA}

Agustina, R. (2014). Proses Berpikir Siswa SMA Dalam Penyelesaian Masalah Aplikasi Turunan Fungsi Ditinjau dari Tipe Kepribadian Choleris. AKSIOMA: Jurnal Program Studi Pendidikan Matematika, 3(1), 50-54.

Agustina, R., \& Farida, N. (2015). Proses Berpikir Siswa SMK Dalam Menyelesaikan Masalah Matematika Ditinjau dari Tipe Kepribadian Phlegmatis. AKSIOMA: Jurnal Program Studi Pendidikan Matematika, 4(1), 1-8.

Argarini, D. F. A., Budiyono, \& Sujadi, I. (2014). Karakteristik Berpikir Kreatif Kelas VII SMP N 1 
Kragan dalam Memecahkan dan Mengajukan Masalah Matematika Materi Perbandingan Ditinjau dari Gaya Kognitif. JMEE, IV(2005), 1-12.

Astuti, R., Budiyono, \& Usodo, B. (2014). Eksperimentasi Model Pembelajaran Kooperatif Tipe TAPPS dan TSTS Terhadap Kemampuan Menyelesaikan Soal Cerita Matematika Ditinjau Dari Tipe Kepribadian Robia. Jurnal Elektronik Pembelajaran Matematika, 2(4), 399-410.

Aziz, A., Kusmayadi, T. A., \& Sujadi, I. (2014). Proses Berpikir Kreatif dalam Pemecahan Masalah Matematika Ditinjau dari Tipe Kepribadian Dimensi Myer-Briggs Siswa Kelas VIII MTs Nw Suralaga Lombok Timur Tahun Pelajaran 2013/2014. Jurnal Elektronik Pembelajaran Matematika ISSN: 2339-1685, 2(10), 1079-1093.

Dewiyani. (2012). The Thinking Process Profile The Students of Informatics System Departement in Solving The Mathematics Problem Based on The Personality Type and Gender. Proceeding. STIKOM Surabaya.

Dewiyani, M. J. S. (2011). Menanamkan Pendidikan Karakter Berbasis Perbedaan Tipe Kepribadian pada Mata Kuliah Matriks dan Transformasi Linear di STIKOM Surabaya. Edumatica, 1(2), 25-34.

Dodi, Hudiono, B., \& Suratman, D. (2015). Analisis Keterampilan Berpikir Kritis siswa pada Materi Limit Fungsi Aljabar di Kelas X SMA. Jurnal Pendidikan Dan Pembelajaran, 4(8), $1-15$.

Effendi, L. A. (2012). Pembelajaran Matematika Dengan Metode Penemuan Terbimbing Untuk Meningkatkan Kemampuan Representasi Dan Pemecahan Masalah Matematis Siswa Smp. Jurnal Penelitian Pendidikan, 1-10.

Fatmawati, H., Mardiyana, \& Triyanto. (2014). Analisis Berpikir Kritis Siswa Dalam Pemecahan Masalah Matematika Berdasarkan Polya pada Pokok Bahasan Persamaan Kuadrat (Penelitian pada Siswa Kelas X SMK Muhammadiyah 1 Sragen Tahun Pelajaran 2013/2014). Jurnal Elektronik Pembelajaran Matematika, 2(9), 911-922.

Fauziyah, I. N. L., Usodo, B., \& Ch., H. E. (2013). Proses Berpikir Kreatif Siswa Kelas X dalam Memecahkan Masalah Geometri Berdasarkan Tahapan Wallas Ditinjau dari Adversity Quotient (AQ) Siswa. Jurnal Pendidikan Matematika Solusi, 1(1), 75-90.

Fitria, C., \& Siswono, T. Y. E. (2014). Profil Keterampilan Berpikir Kreatif Siswa Dalam Memecahkan Masalah Matematika Ditinjau dari Tipe Kepribadian (Sanguinis, Koleris, Melankolis, dan Phlegmatis). MATHEdunesa, 3(3), 23-32.

Hasanah, N., Mardiyana, \& Sutrima. (2013). Analisis Proses Berpikir Siswa Dalam Memecahkan Masalah Matematika Ditinjau dari Tipe Kepribadian Extrovert-Introvert dan Gender. Jurnal Pembelajaran Matematika, 1(4), 422-435.

Hidayah, S. R., Trapsilasiwi, D., \& Setiawani, S. (2016). Proses Berpikir Kritis Siswa Kelas VII F Mts . Al-Qodiri 1 Jember dalam Pemecahan Masalah Matematika Pokok Bahasan 
Segitiga dan Segi Empat ditinjau dari Adversity Quotient. Jurnal Edukasi UNEJ, 3(3), 2126.

Hidayatulloh, Usodo, B., \& Riyadi. (2013). Proses Berpikir Kreatif Siswa SMP dalam Pemecahan Masalah Matematika Ditinjau dari Tipe Kepribadian Siswa. Pembelajaran Matematika, 1(5), 445-456.

Ismaimuza, D. (2011). Kemampuan Berpikir Kritis Matematis Ditinjau dari Pengetahuan Awal Siswa. Jurnal Pendidikan Matematika, 2(1), 11-20.

Lestari, S., \& Wijayanti, P. (2013). Proses Berpikir Kritis Siswa Dala Memecahkan Masalah Matematika Open Ended Ditinjau dari Kemampuan Matematika Siswa dan Perbedaan Jenis Kelamin pada Materi Kubus dan Balok. MATHEdunesa, 3(2).

Lestudy, Imran, \& Yunitaningrum, W. (2013). Kepribadian dan Hasil Belajar Pendidikan Jasmani Olahraga dan Kesehatan Di SMKN 3 Pontianak. Jurnal Pendidikan Dan Pembelajaran, 2(2).

Marfuah, I., Mardiyana, \& Subanti, S. (2016). Proses Berpikir Kritis Peserta Didik Dalam Dua Variabel Ditinjau Dari Gaya Belajar Kelas Ix B Smp Negeri 2 Surakarta Tahun Pelajaran 2015/2016. Jurnal Elektronik Pembelajaran Matematika, 4(7), 622-632.

Nugroho, R. A., Sutinah, \& Setianingsih, R. (2013). Proses Berpikir Siswa Dengan Kecerdasan Linguistik dan Logis Matematis Dalam Memecahkan Masalah Matematika. MATHEdunesa, 3(2)., 3(2).

Rakhmawati, T. Y., Rachmadiarti, F., \& Budiono, J. D. (2015). Analisis Keterampilan Berpikir Kritis Siswa SMA Adiwiyata dan SMA Non- Adiwiyata di Tuban. BioEdu, 4(3), 978-984.

Ramalisa, Y. (2013). Proses Berpikir Kritis Siswa SMA Tipe Kepribadian Thinking Dalam Memecahkan Masalah Matematika. Edumatica, 3(1), 42-47.

Rasiman. (2012). Penelusuran Proses Berpikir Kritis Dalam Menyelesaikan Masalah Matematika Bagi Siswa Dengan Kemampuan Matematika Tinggi. AKSIOMA, 3(1).

Retnowati, D., Sujadi, I., \& Subanti, S. (2016). Proses Berpikir Kritis Siswa Kelas XI Farmasi SMK Citra Medika Sragen Dalam Pemecahan Masalah Matematika. Jurnal Elektronik Pembelajaran Matematika, 4(1), 105-116.

Rohati. (2014). Proses Berpikir Kritis Siswa SMP Tipe Influence Dalam Memecahkan Masalah Matematika. Edumatica, 4(1), 44-50.

Utaminingsih, S., \& Setyabudi, I. (2012). Tipe Kepribadian dan Prokrastinasi Akademik pada Siswa SMA " X" Tangerang. Jurnal Psikologi Volume, 10(1), 48-57.

Widyastuti, R. (2015). Proses Berpikir Siswa dalam Menyelesaikan Masalah Matematika Berdasarkan Teori Polya Ditinjau dari Adversity Quotient Tipe Climber. Al-Jabar : Jurnal Pendidikan Matematika, 6(2), 120-132. 
Wijayanti, D. A. I., Pudjawan, K., \& Margunayasa, I. G. (2015). Analisis Kemampuan Berpikir Kritis Siswa Kelas V Dalam Pembelajaran IPA di 3 SD Gugus X Kecamatan Buleleng. MIMBAR PGSD Undiksha, 3(1).

Zetriuslita, Ariawan, R., \& Nufus, H. (2016). Analisis Kemampuan Berpikir Kritis Matematis Mahasiswa Dalam Menyelesaikan Soal Uraian Kalkulus Integral Berdasarkan Level Kemampuan Mahasiswa. Infinity, 5(1), 56-65. 